\section{A New Route to Cross-Conjugated Bis(enamines) and an Unusual Reaction with DDQ}

\author{
Teresa M. V. D. Pinho e Melo,*,† \\ Ana M. T. D. P. V. Cabral, ${ }^{\dagger}$ \\ António M. d'A. Rocha Gonsalves, ${ }^{\dagger}$ Ana M. Beja, ${ }^{\ddagger}$ \\ J osé A. Paixão, $\neq$ Manuela R. Silva, ${ }^{\ddagger}$ and \\ Luiz Alte da Veiga
}

Departamento de Química and Departamento de Física, Faculdade de Ciências e Tecnol ogia, Universidade de Coimbra, 3000 Coimbra, Portugal

\section{Thomas L. Gilchrist}

Chemistry Department, The University of Liverpool, Liverpool L69 7ZD, U.K.

Received J anuary 26, 1999

In previous papers, we reported that thiazolidines derived from cysteine methyl ester and aldehydes react with silver carbonate and DBU; the reactions produce transient 1-substituted methyl 2-azadiene-3-carboxylates that act as dienes in the Diels-Alder reaction. ${ }^{1}$ When we apply the same procedure to the thiazolidines $\mathbf{1 a - d}$ we find that the products are isolable cross-conjugated bis(enamines) $\mathbf{3 a}-\mathbf{d}$, the more stable tautomers of the azadienes $\mathbf{2 a}-\mathbf{d}$ (Scheme 1 ). This is a new versatile route to enamines of this type.

The diester $\mathbf{3 a}$ is a known compound that has previously been prepared from methyl $\beta$-halo- $\alpha$-aminopropionate hydrohalides by reaction with bases; ${ }^{2}$ compounds 3b-d are previously unknown. Other cross-conjugated bis(enamines) of this type have been produced by thermal rearrangement of vinylaziridines. ${ }^{3}$ These compounds undergo an interesting photocyclization to 3,4-dihydropyrroles that can be intercepted, as 1,3-dipoles, in cycloaddition reactions with alkenes and alkynes. $2 \mathrm{~b}, 3,4$ Compound $3 \mathrm{a}$ is also reported to react as an el ectrophile with hydrazines ${ }^{5}$ and with primary amines, ${ }^{6}$ giving hydrazones and imines of methyl pyruvate as products.

In an attempt to cyclize the diester 3a directly to dimethyl pyrrole-2,5-dicarboxylate by using DDQ as an

\footnotetext{
† Departamento de Química.
}

₹ Departamento de Física.

(1) (a) Gilchrist, T. L.; Rocha Gonsalves, A. M. d'A.; Pinho e Melo, T. M. V. D. Tetrahedron 1994, 50, 13709-13724. (b) Pinho e Melo, T. M. V. D.; Fausto, R.; Rocha Gonsalves, A. M. d'A.; Gilchrist, T. L. J . Org. Chem. 1998, 63, 5350-5355.

(2) (a) Mitsuhashi, K. Asahi Garasu Kogyo Gijutsu Shoreikai Kenkyu Hokoku 1973, 23, 355-362; Chem. Abstr. 1975, 82, 86591. (b) Zaima, T.; Matsunaga, Y.; Mitsuhashi, K. J . Heterocycl. Chem. 1983, 20, 1-4.

(3) Gelas-Mialhe, Y.; Mabiala, G.; Vessière, R. J . Org. Chem. 1987, 52, 5395-5400.

(4) (a) Zaima, T.; Matsuno, C.; Matsunaga, Y.; Mitsuhashi, K. J Heterocycl. Chem. 1984, 21, 445-448. (b) Zaima, T.; Matsuno, C. Matsunaga, Y.; Mitsuhashi, K. Nippon Kagaku Kaishi 1984, 12931298; Chem. Abstr. 1984, 101, 230340.

(5) Zaima, T.; Mitsuhashi, K. Nippon Kagaku Kaishi 1979, 901905; Chem. Abstr. 1979, 91, 140303.

(6) Zaima, T.; Matsuno, C.; Mitsuhashi, K. Nippon Kagaku Kaishi 1983, 152-156; Chem. Abstr. 1983, 98, 179141.

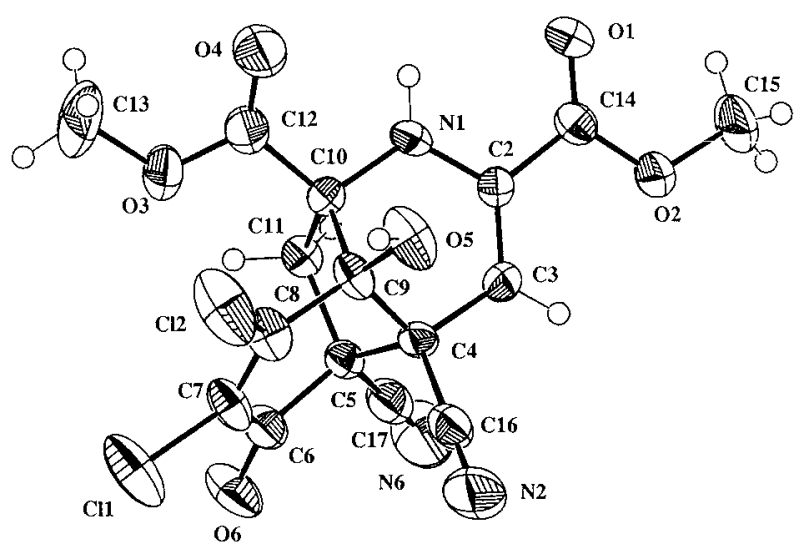

Figure 1. X-ray structure of compound 4.

\section{Scheme 1}
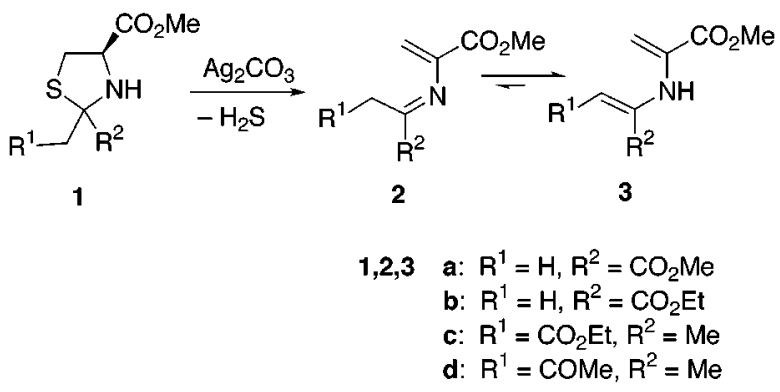

oxidant, a single product was isolated in high yield. Instead of the pyrrole, it proved to be an interesting 1:1 adduct of the diester and DDQ whose structure 4 was established for the compound by X-ray crystallography (Figure 1).

The X-ray analysis clearly shows that the C9-C10$\mathrm{N} 1-\mathrm{C} 2-\mathrm{C} 3-\mathrm{C} 4$ and $\mathrm{C} 4-\mathrm{C} 5-\mathrm{C} 6-\mathrm{C} 7-\mathrm{C} 8-\mathrm{C} 9$ rings are fused cis around the common $\mathrm{C} 4-\mathrm{C} 9$ bond and are furthermore linked by the methylenic bridge C10-C11$\mathrm{C} 5$. The conformation of the two above-mentioned rings is intermediate between $\mathrm{E}^{1}$ envel ope and ${ }^{1} \mathrm{H}_{2}$ half-chair, as shown by the ring puckering parameters ${ }^{7} \mathrm{Q}=0.662$ (4) $\AA, \theta=53.8(3)^{\circ}, \phi=13.9(4)^{\circ}[\mathrm{C} 9-\mathrm{C} 10-\mathrm{N} 1-\mathrm{C} 2-\mathrm{C} 3-$ C4], $\mathrm{Q}=0.630(4) \AA, \theta=53.8(4)^{\circ}, \phi=8.2(5)^{\circ}[\mathrm{C} 4-\mathrm{C} 5-$ $\mathrm{C} 6-\mathrm{C} 7-\mathrm{C} 8-\mathrm{C} 9]$. The conformation of the bridging ring $\mathrm{C} 4-\mathrm{C} 5-\mathrm{C} 11-\mathrm{C} 10-\mathrm{C} 9$ is very close to ${ }^{5} \mathrm{~T}_{1}$ (twisted around the C4-C9 bond), as shown by the puckering parameters $\mathrm{Q}(2)=0.566(4) \AA, \phi(2)=163.3(4)^{\circ}$. The $\mathrm{H} 1$ atom is shared in a bifurcated intramolecular hydrogen bond

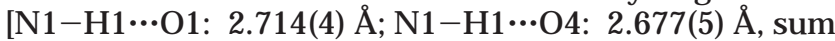
of the valence angles around $\mathrm{HI}=358.2^{\circ}$. The methoxycarbonyl group attached to the $\mathrm{sp}^{2} \mathrm{C} 2$ atom is almost coplanar with the plane defined by the C10-N1-C2 atoms, whereas the other methoxycarbonyl group that is attached to the tetrahedric C10 atom is twisted by $-16.9(5)^{\circ}$ around the $\mathrm{C} 10-\mathrm{C} 12$ single bond. The $\mathrm{H} 5$ atom of the hydroxyl group is also involved in a bifurcated

(7) Cremer, D.; Pople, J . A. J . Am. Chem. Soc. 1975, 97, 1354. 
Scheme 2

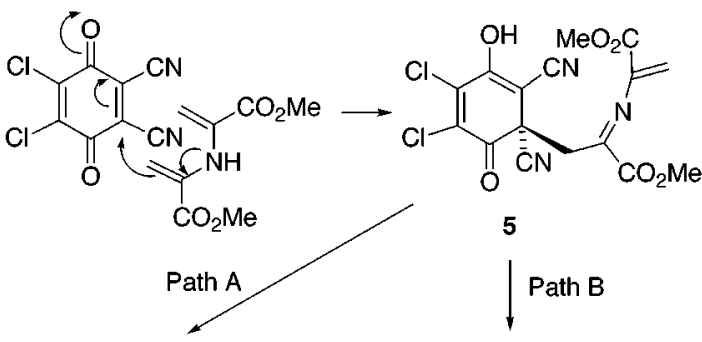

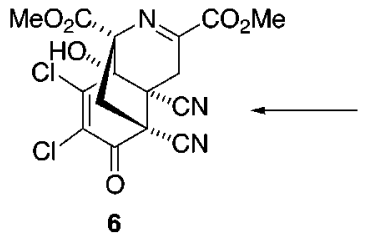

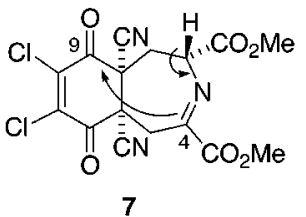

1

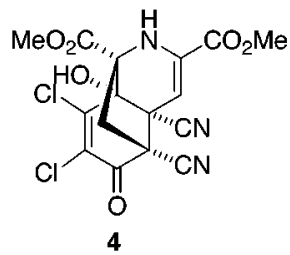<smiles>CC(=O)C1=N[C@](C)(C(C)=O)C[C@@]2(C)C(=O)C(=O)C(Cl)=C(Cl)C2(C)C1=O</smiles>

hydrogen bond, being donated to both the $\mathrm{Cl} 2$ atom [O5H5...Cl2: $2.922(3) \AA]$ and to the carbonyl $\mathrm{O} 1$ atom of a neighboring molecule $\left[05-\mathrm{H} 5 \cdots \mathrm{O} 1^{\mathrm{i}} 2.815(4) \AA\right.$, i $=1 / 2-$ $\mathrm{x}, 1 / 2+\mathrm{y}, 1-\mathrm{z}]$.

In the Nenitzescu indole synthesis, p-benzoquinones react with primary enamides to produce 5-hydroxyindoles. The first step is a conjugate addition of the enamide, through the $\beta$-carbon atom, to benzoquinone. We suggest that, in a similar way, 3a first reacts with DDQ by conjugate addition to give the intermediate $\mathbf{5}$ (Scheme 2). Two possible ways in which this intermediate could be converted into the final product $\mathbf{4}$ are shown in Scheme 2. The most direct route (path A) is an intramolecular Diels-Alder reaction in which the enol of the sixmembered ring acts as the dienophile, giving compound 6 that would be expected to tautomerize to the final product 4. An alternative (path $B$ ) is a second conjugate addition reaction to give the tetrahydroazepine 7 . The lowest energy conformation of compound 7, as determined by molecular mechanics calculations, ${ }^{8-10}$ is illustrated in Figure 2a. The estimated distance between the reacting centers ( $C 4$ and $C 9$ ) is $4.13 \AA$, and they are suitably aligned to promote a second cyclization to compound $\mathbf{6}$. In contrast, the more stable conformation of the isomer $\mathbf{8}$, shown in Figure $2 \mathrm{~b}$, does not favor the cyclization step. Path $B$ therefore requires the intermediacy of compound 7, either formed stereoselectively in the conjugate addition step or by epimerization of $\mathbf{8}$.

The formation of an adduct of this type with benzoquinones has not previously been reported, so we carried out a limited investigation of the scope of the reaction. As expected, compound $\mathbf{3 b}$ also reacted with DDQ to give

(8) (a) Molecular mechanics PCFF 300 (101) force fiel d 9 calculations were undertaken using the Cerius ${ }^{2}$ (version 3.5) molecular modeling program. ${ }^{10}$

(9) (a) Sun, H. J . Comput. Chem. 1994, 15, 752. (b) Sun, H.; Mumby, S. J .; Maple, J. R.; Hagler, A. T. J . Am. Chem. Soc. 1994, 116, 2978.

(10) Cerius $^{2}$ (version 3.5), Molecular Simulation, San Diego, CA 92111-3712, 1997. a)

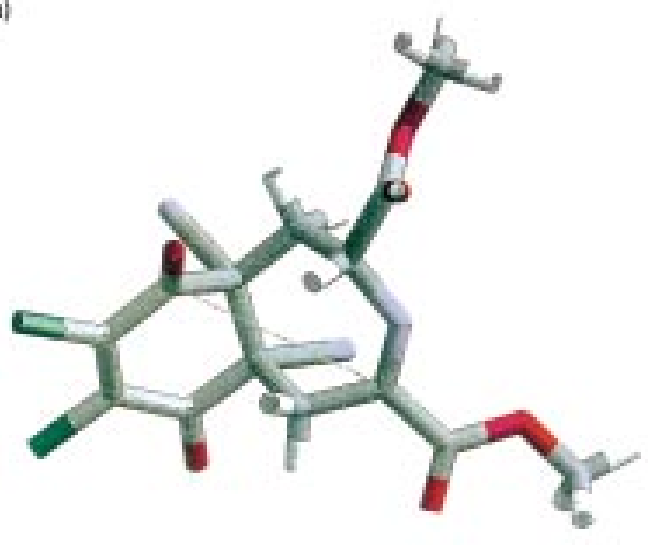

b)

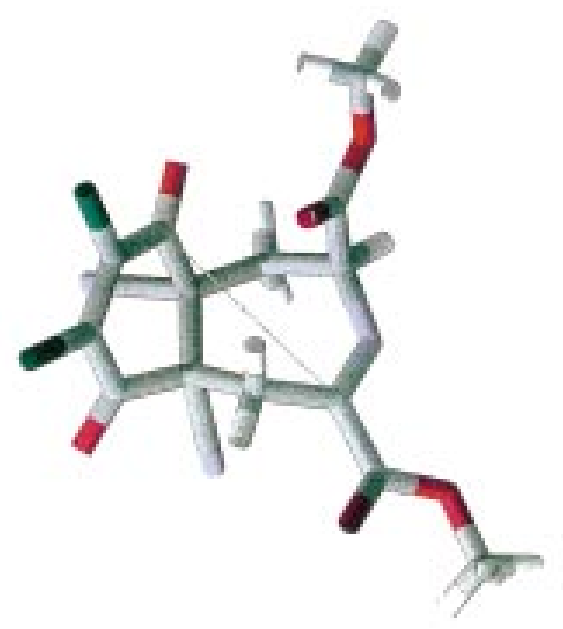

Figure 2. Lowest energy conformation of $\mathbf{7}$ (a) and 8 (b) determined by molecular mechanics calculations. ${ }^{8-10}$

in this case the adducts $\mathbf{9}$ and $\mathbf{1 0}$ as an inseparable mixture in a 1:1 ratio. The mechanism would lead the bis(enamines) $\mathbf{3 c}$ and $\mathbf{3 d}$ to give complex mixtures under the same conditions as we experimentally observed.<smiles>CCOC[C@H]1NC(C(C)=O)=C[C@@]2(C#N)[C@H](O)C(Cl)=C(Cl)C(=O)[C@]12C#N</smiles>

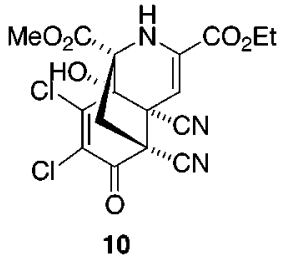

Reactions of the diester $3 a$ with electrophilic alkenes were briefly investigated. With methyl vinyl ketone it gave the tetrahydropyridine $\mathbf{1 1}$ in moderate yield. The formation of this product can also be rationalized as a conjugate addition-cyclization sequence, somewhat analogous to the Hantzsch dihydropyridine synthesis ${ }^{11}$ (Scheme 3).

This work provided a novel route to cross conjugated bis(enamines), useful building blocks for the synthesis of nitrogen containing heterocycles. ${ }^{2-4}$ We are currently expl oring the asymmetric reduction of these compounds as a source of new amino acids. An unusual reaction of

(11) Katritzky, A. R.; Ostercamp, D. L.; Yousaf, T. I. Tetrahedron 1987, 43, 5171-5186. 


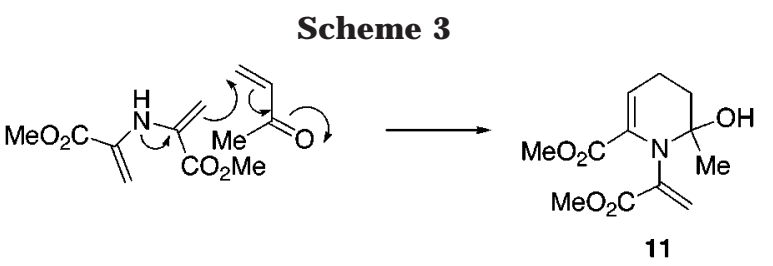

2-iminobis(propenoic) diester with DDQ is described, and this led to the novel structures $\mathbf{4}, \mathbf{9}$, and $\mathbf{1 0 .}$

\section{Experimental Section}

General Methods. General methods of characterization have been described previously. ${ }^{\text {la }}$ Light petroleum refers to the fraction bp $40-60^{\circ} \mathrm{C}$. Thiazolidines $\mathbf{1 a}-\mathbf{d}$ were prepared by the general procedure described earlier, starting from L-cysteine methyl ester hydrochloride. ${ }^{1 a}$ A preparation of the thiazolidine 1c has been described in the literature, ${ }^{12}$ and the thiazolidine 1 a has been described as a component of a reaction mixture. ${ }^{13}$

Dimethyl 2-Methylthiazolidine-2,4-dicarboxylate (1a). Compound 1a (diastereoisomeric mixture 82:18) was obtained as an oil (90\%): IR (film) $1740 \mathrm{~cm}^{-1} ;{ }^{1} \mathrm{H}$ NMR $\left(\mathrm{CDCl}_{3}, 200 \mathrm{MHz}\right)$ $\delta 1.94$ and $2.11(3 \mathrm{H}, 2 \times \mathrm{s}), 3.11(1 \mathrm{H}, \mathrm{t}, \mathrm{J}=10.44 \mathrm{~Hz}), 3.62(1$ $\mathrm{H}, \mathrm{dd}, \mathrm{J}=5.5,10.2 \mathrm{~Hz}), 4.03,4.04$ and $4.05(6 \mathrm{H}, 3 \times \mathrm{s})$, and $4.26\left(1 \mathrm{H}, \mathrm{dd}, \mathrm{J}=5.5,10.4 \mathrm{~Hz}\right.$ ); MS (EI) $220\left(\mathrm{M}^{+}, 0.5\right), 160$ (100), 119 (49), 100 (92), and 59 (85). Anal. Calcd for $\mathrm{C}_{8} \mathrm{H}_{13} \mathrm{NO}_{4} \mathrm{~S}$ : C, 43.83; H, 5.93; N, 6.39. Found: C, 43.39; H, 5.90; N, 6.25.

2-Ethyl 4-Methyl 2-Methylthiazolidine-2,4-dicarboxylate (1b). Compound $\mathbf{1 b}$ (diastereoisomeric mixture 80:20) was obtained as an oil (87\%): IR (film) $1738 \mathrm{~cm}^{-1}$; ${ }^{1} \mathrm{H} \mathrm{NMR}\left(\mathrm{CDCl}_{3}\right.$, $200 \mathrm{MHz}) \delta 1.32(3 \mathrm{H}, \mathrm{t}), 1.70$ and $1.87(3 \mathrm{H}, 2 \times \mathrm{s}), 2.88(1 \mathrm{H}$, $\mathrm{t}, \mathrm{J}=10.45 \mathrm{~Hz}), 3.38(1 \mathrm{H}, \mathrm{dd}, \mathrm{J}=5.77,10.45 \mathrm{~Hz}), 3.80$ and $3.81(3 \mathrm{H}, 2 \times \mathrm{s}), 4.03(1 \mathrm{H}, \mathrm{dd}, \mathrm{J}=5.77,10.45 \mathrm{~Hz})$, and $4.27(2$ $\mathrm{H}, \mathrm{q})$; MS (EI) 234 (M+, 10), 160 (100), 119 (89), 100 (100), and 59 (93). Anal. Calcd for $\mathrm{C}_{9} \mathrm{H}_{15} \mathrm{NO}_{4} \mathrm{~S}$ : C, 46.35; $\mathrm{H}, 6.43 ; \mathrm{N}, 6.00$. Found: C, 46.38; H, 6.60; N, 6.11.

Methyl 2-Methyl-2-(ethoxycarbonylmethyl)thiazolidine4-carboxylate (1c). Compound 1c (diastereoisomeric mixture 72:28) was obtained as an oil (90\%): IR (film) $1743 \mathrm{~cm}^{-1}$; ${ }^{1} \mathrm{H}$ NMR $\left(\mathrm{CDCl}_{3}, 200 \mathrm{MHz}\right) \delta 1.22-1.32(3 \mathrm{H}, \mathrm{m}), 1.57$ and $1.84(3$ $\mathrm{H}, 2 \times \mathrm{s}), 2.76$ and $2.88(2 \mathrm{H}, 2 \times \mathrm{s}), 2.91-3.20(1 \mathrm{H}, \mathrm{m}) 3.35-$ $3.45(1 \mathrm{H}, \mathrm{m}), 3.79$ and $3.80(3 \mathrm{H}, 2 \times \mathrm{s}), 4.04-4.13(1 \mathrm{H}, \mathrm{m})$, and 4.07-4.24 (2 H, m); MS (EI) $247\left(\mathrm{M}^{+}, 16\right), 214(20), 188$ (57), 160 (100), 100 (96), and 59 (58).

Methyl 2-Methyl-2-(acetylmethyl)thiazolidine-4-carboxylate (1d). The reaction of cysteine methyl ester with acetylacetone led to the formation of two products: the expected thiazolidine 1d (diastereoisomeric mixture 57:43) was formed in $62 \%$ yield and $\mathrm{N}$-(4-oxobut-2-ene)cysteine methyl ester disulfide in $8 \%$ yield. The products were isolated by flash chromatography light petroleum-ethyl acetate (2:1), light petroleumethyl acetate (1:1) then ethyl acetate]. Compound 1d was obtained as an oil: IR (film) $1742 \mathrm{~cm}^{-1}$; ${ }^{1} \mathrm{H}$ NMR $\left(\mathrm{CDCl}_{3}, 200\right.$ $\mathrm{MHz}) \delta 1.97$ and $2.04(3 \mathrm{H}, 2 \times \mathrm{s}), 2.18$ and $2.25(3 \mathrm{H}, 2 \times \mathrm{s})$, 2.80-3.06 and 3.28-3.39 $(2 \mathrm{H}, \mathrm{m}), 3.78$ and $3.80(3 \mathrm{H} 2 \times \mathrm{s})$, and 4.02-4.04, and 4.37-4.44 (1 H, m); MS (EI) $217\left(\mathrm{M}^{+}, 68\right)$, 202 (11), 158 (87), 128 (52), and 110 (100). Anal. Calcd for $\mathrm{C}_{9} \mathrm{H}_{15}$ $\mathrm{NO}_{3} \mathrm{~S}$ : C, 49.75; $\mathrm{H}, 6.96 ; \mathrm{N}, 6.45$. Found: C, 49.67; H, 7.02; N, 6.62.

N-[2-(4-oxo-pent-2-ene)]cysteine methyl ester disulfide: $\mathrm{mp} 106-107{ }^{\circ} \mathrm{C}$ (from dichloromethane-diethyl ether); I R (KBr) $1734 \mathrm{~cm}^{-1} ;{ }^{1} \mathrm{H} \mathrm{NMR}\left(\mathrm{CDCl}_{3}, 200 \mathrm{MHz}\right) \delta 1.95(6 \mathrm{H}, \mathrm{s}), 2.03(6$ $\mathrm{H}, \mathrm{s}), 2.98(2 \mathrm{H}, \mathrm{dd}, \mathrm{J}=8.2,14.0 \mathrm{~Hz}), 3.20(2 \mathrm{H}, \mathrm{dd}, \mathrm{J}=5.2$, $14.0 \mathrm{~Hz}), 3.78(6 \mathrm{H}, \mathrm{s}) .4 .45-4.52(2 \mathrm{H}, \mathrm{m})$, and $5.07(2 \mathrm{H}, \mathrm{s}) ;{ }^{13} \mathrm{C}$ NMR $\left(\mathrm{CDCl}_{3}, 50.3 \mathrm{MHz}\right) \delta 19.0,28.9,40.8,52.7,54.8,97.2,161.0$, 170.3, and 196.2; MS (EI) $433\left(\mathrm{M}^{+}, 8\right), 249$ (16), 216 (87), 174 (51), 142 (17), and 114 (26). Anal. Calcd for $\mathrm{C}_{18} \mathrm{H}_{28} \mathrm{~N}_{2} \mathrm{O}_{6} \mathrm{~S}_{2}$ : C, 49.98; H, 6.52; N, 6.48. Found: C, 49.85; H, 6.52; N, 6.21.

Preparation of Bis(enamines). General Procedure. The thiazolidine $\mathbf{1}$ ( $1.0 \mathrm{mmol}$ ) was dissolved in dry acetonitrile (10

(12) Cook, A. H.; Heilbron, I. M. In The Chemistry of Penicillin; Princeton University Press: Princeton, NJ , 1949; p 964.

(13) Hill, R. W.; Robinson, S. J . Chem. Commun. 1996, 843-844.
$\mathrm{mL})$. The solution was cooled to $-20^{\circ} \mathrm{C}$, and silver carbonate ( $277 \mathrm{mg}, 1 \mathrm{mmol}$ ) was added, followed by a solution of DBU (30 $\mathrm{mg}, 0.2 \mathrm{mmol}$ ) in dry acetonitrile $(5 \mathrm{~mL})$. The reaction mixture was stirred for $2 \mathrm{~h}$ at $0{ }^{\circ} \mathrm{C}$ and then for $8 \mathrm{~h}$ at room temperature. Diethyl ether was added, the reaction mixture was filtered, and the solvent was evaporated from the filtrate. The products were isolated by flash chromatography.

2-Iminobis(propenoic acid) Dimethyl Ester (3a). Dimethyl 2-methylthiazolidine-2,4-dicarboxylate la gave, by the general procedure, followed by flash chromatography [light petroleum-ethyl acetate (4:1) then light petroleum-ethyl acetate (3:1)] 2-iminobis(propenoic acid) dimethyl ester 3a as a yellow solid (139 mg, $75 \%$ ): $\mathrm{mp} 44-45^{\circ} \mathrm{C}$ (lit. ${ }^{2 b} \mathrm{mp} 51-51.5^{\circ} \mathrm{C}$ ); IR (film) 1724 and $1624 \mathrm{~cm}^{-1}$; ${ }^{1} \mathrm{H}$ NMR $\left(\mathrm{CDCl}_{3}, 200 \mathrm{MHz}\right) \delta 3.85$ $(\mathrm{s}, 6 \mathrm{H}), 5.06(\mathrm{~m}, 2 \mathrm{H})$, and $5.55(\mathrm{~m}, 2 \mathrm{H}) ;{ }^{13} \mathrm{C} \mathrm{NMR}\left(\mathrm{CDCl}_{3}, 50.3\right.$ $\mathrm{MHz}): \delta 52.9,97.3,134.1$, and 165.1; MS (EI) $185\left(\mathrm{M}^{+}, 66\right), 153$ (100), 94 (86), and 66 (64). Anal. Calcd for $\mathrm{C}_{8} \mathrm{H}_{11} \mathrm{NO}_{4}$ : C, 51.89; H, 5.94; N, 7.56. Found: C, 51.99; H, 6.06; N, 7.35.

2-Iminobis(propenoic acid) Ethyl Methyl Ester (3b). 2-Ethyl 4-methyl 2-methylthiazolidine-2,4-dicarboxylate 91b) gave, by the general procedure, followed by flash chromatography [light petroleum-ethyl acetate (4:1) then light petroleumethyl acetate (3:1)] 2-iminobis(propenoic acid) ethyl methyl ester (3b) (101 mg, 51\%) (as an oil at room temperature, solid with low mp): IR (film) 1724 and $1626 \mathrm{~cm}^{-1}$; ${ }^{1} \mathrm{H} \mathrm{NMR}\left(\mathrm{CDCl}_{3}, 200\right.$ $\mathrm{MHz}) \delta 1.35(\mathrm{t}, 3 \mathrm{H}), 3.85(\mathrm{~s}, 3 \mathrm{H}), 4.30(\mathrm{q}, 2 \mathrm{H}), 5.03-5.05(\mathrm{~m}$, $2 \mathrm{H}), 5.53-5.54(\mathrm{~m}, 2 \mathrm{H})$, and $7.35(\mathrm{~s}, 1 \mathrm{H}) ;{ }^{13} \mathrm{C} \mathrm{NMR}\left(\mathrm{CDCl}_{3}\right.$, $50.3 \mathrm{MHz}) \delta 14.1,52.8,62.0,96.9,97.1,134.1,134.3,164.5$, and 165.0; MS (EI) $199\left(\mathrm{M}^{+}, 80\right), 167$ (55), 153 (96), 94 (73), and 66 (88). Anal. Calcd for $\mathrm{C}_{9} \mathrm{H}_{13} \mathrm{NO}_{4}: \mathrm{C}, 54.27 ; \mathrm{H}, 6.53 ; \mathrm{N}, 7.03$. Found: C, 54.15; H, 6.56; N, 7.06.

3-(1-Methoxycarbonylvinylamino)but-2-enoic Acid Ethyl Ester (3c). Methyl 2-(ethoxycarbonyl methyl)-2-methylthiazolidine-4-carboxylate (1c) gave, by the general procedure, followed by flash chromatography [light petroleum-ethyl acetate (4:1) then light petroleum-ethyl acetate (3:1)] 3-(1-methoxycarbonylvinylamino)but-2-enoic acid ethyl ester (3c) (107 mg, 50\%) (as an oil at room temperature, solid with low $\mathrm{mp}$ ): ${ }^{1} \mathrm{H}$ NMR $\left(\mathrm{CDCl}_{3}, 200 \mathrm{MHz}\right) \delta 1.26(\mathrm{t}, 3 \mathrm{H}), 2.10(\mathrm{~s}, 3 \mathrm{H}), 3.85(\mathrm{~s}, 3 \mathrm{H})$, $4.11(\mathrm{q}, 2 \mathrm{H}), 4.72(\mathrm{~s}, 1 \mathrm{H}), 5.17(\mathrm{~s}, 1 \mathrm{H})$, and $5.71(\mathrm{~s}, 1 \mathrm{H})$. Anal. Calcd for $\mathrm{C}_{10} \mathrm{H}_{15} \mathrm{NO}_{4}$ : C, 56.33; $\mathrm{H}, 7.04 ; \mathrm{N}, 6.57$. F ound: $\mathrm{C}, 56.41$; $\mathrm{H}, 7.09 ; \mathrm{N}, 6.49$.

Methyl 2-(1-Methyl-3-oxo-but-1-enylamino)acrylate (3d). Methyl 2-(acetylmethyl)-2-methylthiazolidine-4-carboxylate (1d) gave, by the general procedure, followed by flash chromatography [light petroleum-ethyl acetate (4:1) then light petroleumethyl acetate (3:1)] methyl 2-(1-methyl-3-oxo-but-1-enylamino)acrylate (3d) (130 mg, 71\%): $\mathrm{mp} 52-53{ }^{\circ} \mathrm{C} ;{ }^{1} \mathrm{H} \mathrm{NMR}\left(\mathrm{CDCl}_{3}\right.$, $200 \mathrm{MHz}) \delta 2.09(\mathrm{~s}, 6 \mathrm{H}), 3.85(\mathrm{~s}, 3 \mathrm{H}), 5.21(\mathrm{~s}, 1 \mathrm{H}), 5.32(\mathrm{~s}, 1 \mathrm{H})$, and $5.89(\mathrm{~s}, 1 \mathrm{H}) ;{ }^{13} \mathrm{C} \mathrm{NMR}\left(\mathrm{CDCl}_{3}, 50.3 \mathrm{MHz}\right) \delta 20.0,29.0,52.6$, 99.9, 110.1, 133.9, 157.4, 163.9, and 196.4; MS (EI) $183\left(\mathrm{M}^{+}\right.$, 22), 168 (4), 140 (40), 124 (14), and 108 (41). Anal. Calcd for $\mathrm{C}_{9} \mathrm{H}_{13} \mathrm{NO}_{3}$ : C, 59.00; $\mathrm{H}, 7.15 ; \mathrm{N}, 7.65$. Found: $\mathrm{C}, 59.06 ; \mathrm{H}, 6.90$; N, 7.39.

Preparation of 4-0xo-11-azatricyclo[5.4.0.03,8]undeca5,9-dienes. General Procedure. A solution of the divinylamine $(6.23 \mathrm{mmol})$ in toluene $(40 \mathrm{~mL})$ was stirred under nitrogen, and DDQ (1.47 g, $6.5 \mathrm{mmol})$ was added. The resulting mixture was heated under reflux for $2.5 \mathrm{~h}$. The product precipitated on cooling and was isolated by filtration.

5,6-Dichloro-3,8-dicyano-7-hydroxy-4-oxo-11-azatricyclo[5.4.0.03,8] undeca-5,9-diene-1,10-dicarboxylic Acid Dimethyl Ester (4). Product 4 was isolated as a yellow solid (2.46 g, 96\%): $\mathrm{mp} 209-211^{\circ} \mathrm{C}$ (from diethyl ether-light petroleum bp $\left.40-60{ }^{\circ} \mathrm{C}\right) ; \mathrm{IR}(\mathrm{KBr}) 2256,1719,1635,1570 \mathrm{~cm}^{-1} ;{ }^{1} \mathrm{H}$ NMR $\left(\mathrm{CDCl}_{3}, 200 \mathrm{MHz}\right) \delta 2.85(\mathrm{~d}, 1 \mathrm{H}, \mathrm{J}=15.0 \mathrm{~Hz}), 2.97(\mathrm{~d}, 1 \mathrm{H}, \mathrm{J}$ $=15.0 \mathrm{~Hz}), 3.87(\mathrm{~s}, 3 \mathrm{H}), 3.91(\mathrm{~s}, 3 \mathrm{H}), 5.59(\mathrm{~s}, 1 \mathrm{H})$, and $5.89(\mathrm{~s}$, $1 \mathrm{H}) ;{ }^{13} \mathrm{C} \mathrm{NMR}\left(\mathrm{CDCl}_{3}, 50.3 \mathrm{MHz}\right) \delta 41.8,53.4,56.0,63.4,67.9$, 77.8, 102.5, 113.2, 113.9, 130.1, 135.5, 154.7, 161.5, 166.1, and 178.3; MS (FAB) $411\left[\mathrm{M}^{+}\left({ }^{35} \mathrm{Cl}\right)\right.$, 34]. Anal. Calcd for $\mathrm{C}_{16} \mathrm{H}_{11-}$ $\mathrm{Cl}_{2} \mathrm{~N}_{3} \mathrm{O}_{6}$ : C, 46.62; $\mathrm{H}, 2.69 ; \mathrm{N}, 10.19$. Found: $\mathrm{C}, 46.61 ; \mathrm{H}, 2.70$; $\mathrm{N}, 10.19$.

5,6-Dichloro-3,8-dicyano-7-hydroxy-4-oxo-11-azatricyclo[5.4.0.03,8] undeca-5,9-diene-1,10-dicarboxylic acid 1-Ethyl 10-Methyl Ester (9) and 5,6-Dichloro-3,8-dicyano-7-hydroxy-4-oxo-11-azatricyclo[5.4.0.03,8] undeca-5,9-diene-1,10dicarboxylic Acid 10-Ethyl 1-Methyl Ester (10). The 1:1 
mixture of $\mathbf{9}$ and $\mathbf{1 0}$ was isolated by filtration as a yellow solid ( $2.3 \mathrm{~g}, 87 \%$ ): $\mathrm{mp} 194-196{ }^{\circ} \mathrm{C}$ (from diethyl ether-light petroleum bp $\left.40-60^{\circ} \mathrm{C}\right) ;{ }^{1} \mathrm{H}$ NMR $\left(\mathrm{CDCl}_{3}, 200 \mathrm{MHz}\right) \delta 1.33(\mathrm{t}, 3 \mathrm{H})$, $1.39(\mathrm{t}, 3 \mathrm{H}), 2.84(\mathrm{~d}, 1 \mathrm{H}, \mathrm{J}=15.6 \mathrm{~Hz}), 2.85(\mathrm{~d}, 1 \mathrm{H}, \mathrm{J}=15.3$ $\mathrm{Hz}), 2.96(\mathrm{~d}, 1 \mathrm{H}, \mathrm{J}=15.6 \mathrm{~Hz}), 2.97(\mathrm{~d}, 1 \mathrm{H}, \mathrm{J}=15.3 \mathrm{~Hz}), 3.88$ (s, $3 \mathrm{H}), 3.91(\mathrm{~s}, 3 \mathrm{H}), 4.35(\mathrm{q}, 2 \mathrm{H}), 4.36(\mathrm{q}, 2 \mathrm{H}), 5.56(\mathrm{bs}, 2 \mathrm{H})$, and $5.88(\mathrm{~m}, 2 \mathrm{H}) ;{ }^{13} \mathrm{C} \mathrm{NMR}\left(\mathrm{CDCl}_{3}, 50.3 \mathrm{MHz}\right) \delta 13.7,14.0$, 41.8, 41.9, 53.4, 54.7, 56.0, 56.1, 63.0, 63.3, 64.6, 67.8, 67.9, 77.8, 77.9, 102.2, 102.5, 113.2, 135.5, 135.6, 154.5, 161.0, 161.5, 165.7, 165.7, and 178.3; MS (FAB) $426\left[\mathrm{M}^{+}\left({ }^{35} \mathrm{Cl}\right), 85\right]$. Anal. Calcd for $\mathrm{C}_{17} \mathrm{H}_{13} \mathrm{Cl}_{2} \mathrm{~N}_{3} \mathrm{O}_{6}: \mathrm{C}, 47.91 ; \mathrm{H}, 3.07 ; \mathrm{N}, 9.86$. Found: $\mathrm{C}, 47.72 ; \mathrm{H}$, 3.05; N, 9.91 .

6-Hydroxy-1-(1-methoxycarbonylvinyl)-6-methyl-1,4,5,6tetrahydropyridine-2-carboxylic Acid Methyl Ester (11). A solution of the divinylamine $3 a(185 \mathrm{mg}, 1.0 \mathrm{mmol})$ in methyl vinyl ketone ( $5 \mathrm{~mL}$ ) was maintained at room temperature for $48 \mathrm{~h}$. The excess methyl vinyl ketone was distilled off, and the residue was subjected to flash chromatography. This gave [with light petroleum ether (4:1), light petroleum-ethyl acetate (3:1) then ethyl acetate] the tetrahydropyridine $\mathbf{1 1}$ (102 mg, 40\%) as an oil: IR (film) 3404, 1751, 1717, and $1689 \mathrm{~cm}^{-1}$; ${ }^{1} \mathrm{H}$ NMR $\left(\mathrm{CDCl}_{3}, 200 \mathrm{MHz}\right) \delta 1.71-1.72(\mathrm{~m}, 4 \mathrm{H}), 1.90-2.10(\mathrm{~m}, 3 \mathrm{H})$, $3.68(\mathrm{~s}, 3 \mathrm{H}), 3.71(\mathrm{~s}, 3 \mathrm{H}), 4.50(\mathrm{brt}, 1 \mathrm{H}), 4.81(\mathrm{~d}, 1 \mathrm{H}$, J $=1.1$ $\mathrm{Hz}), 5.01(\mathrm{~s}, 1 \mathrm{H})$, and $5.05-5.06(\mathrm{~m}, 1 \mathrm{H}) ;{ }^{13} \mathrm{C} \mathrm{NMR}\left(\mathrm{CDCl}_{3}\right.$, $50.3 \mathrm{MHz}$ ) $\delta 17.6(\mathrm{t}), 19.7(\mathrm{q}), 29.8(\mathrm{t}), 52.7(\mathrm{q}), 52.8(\mathrm{q}), 85.4(\mathrm{~s})$, $95.0(\mathrm{~d}), 95.6(\mathrm{t}), 175.7(\mathrm{~s}), 148.3(\mathrm{~s}), 165.3(\mathrm{~s})$, and $170.6(\mathrm{~s})$; MS
(EI) $255\left(\mathrm{M}^{+}, 1\right), 194$ (53), 151 (50), 134 (43), and 91 (44). Anal. Calcd for $\mathrm{C}_{12} \mathrm{H}_{17} \mathrm{NO}_{5}$ : C, 56.47; $\mathrm{H}, 6.66 ; \mathrm{N}, 5.49$. F ound: C, 56.20; $\mathrm{H}, 6.86 ; \mathrm{N}, 5.06$.

Crystallographic Data for 5,6-Dichloro-3,8-dicyano-7hydroxy-4-oxo-11-azatricyclo[5.4.0.03,8]undeca-5,9-diene1,10-dicarboxylic Acid Dimethyl Ester (4). X-ray diffraction analysis on compound $\mathbf{4}$ was carried out on a Enraf Nonius CAD-4 diffractometer at room temperature. The structure of this compound $\left(\mathrm{C}_{16} \mathrm{H}_{11} \mathrm{Cl}_{2} \mathrm{~N}_{3} \mathrm{O}_{6}, \mathrm{M}_{\mathrm{w}} 412.18 \mathrm{amu}\right.$ ) was determined from a prismatic crystal of dimensions $0.07 \times 0.10 \times 0.15 \mathrm{~mm}$ (space group $P 2_{1} / a$ ) with unit cell $a=10.522(5) \AA, b=13.014$ (6) $\AA, c=13.386(6) \AA, \beta=97.57(4)^{\circ}, V=1817.0(15) \AA^{3}$. It was four molecules per cell, $D_{\mathrm{x}}=1.507 \mathrm{gcm}^{-3}, \mu=0.396 \mathrm{~mm}^{-1}$. Mo $\mathrm{K} \alpha(\lambda=0.71073 \AA) .2204$ reflections with I $>2 \sigma(\mathrm{I}), \mathrm{R}_{\mathrm{w}}=0.035$.

Acknowledgment. We thank Dr. Rui Fausto (Universidade de Coimbra) for the molecular mechanics calculations, Chymiotechnon and PRODEP for financial support, and Faculdade de Farmácia, Universidade de Coimbra, for a leave of absence (A.M.T.D.P.V.C.).

Supporting Information Available: Crystal lographic data for $\mathbf{4}$. This material is available free of charge via the Internet at http://pubs.acs.org.

J 09901384 